\title{
Кенешбаев Д.К. \\ Анализ влияния пандемии COVID-19 на развитие банковского сектора России
}

ФГОБУВО Финансовый университет при Правительстве Российской Федераџии

(Россия, Москва)

doi: 10.18411/trnio-12-2021-32

\section{Аннотация}

Период пандемии COVID-19 стал сложным этапом для функционирования большинства отраслей, как в России, так и на международном уровне. Особенность данного периода заключается в его нестандартности - большинство предприятий вынуждены были изменить формат работы, приспособиться к государственным регламентам в максимально короткие сроки. Банковская сфера также относится к перечню таких организаций.

В связи с указанным, в статье проводится анализ опыта российских банков относительно изменения своего функционирования в период пандемии COVID-19, рассматриваются факторы, повлиявшие на работу банковской сферы, а также выявляются возникшие проблемы в данной сфере и определяются возможные перспективные пути решения их.

Ключевые слова: банковский сектор, операционная эффективность, трансформация бизнес-процессов, цифровизация бизнеса, стоимость обслуживания клиентов, ключевая ставка кредитования.

\section{Abstract}

The period of the COVID-19 pandemic has become a difficult stage for the functioning of most industries, both in Russia and internationally. The peculiarity of this period lies in its nonstandard nature - most enterprises were forced to change the format of work, adapt to state regulations as soon as possible. The banking sector also belongs to the list of such organizations.

In connection with the above, the article analyzes the experience of Russian banks regarding changes in their functioning during the COVID-19 pandemic, examines the factors that influenced the work of the banking sector, as well as identifies the problems that have arisen in this area and identifies possible promising ways to solve them.

Keywords: banking sector, operational efficiency, transformation of business processes, business digitalization, customer service cost, key lending rate.

Пандемия COVID-19 оказала влияние на трансформацию форм работы множества отраслей, в том числе и на банковский сектор. Одновременно с этим, финансовые учреждения в целом достаточно быстро адаптировались к измененным условиям работы.

Наиболее крупные банки в 2020 году имели устойчивую динамику бизнеса и смогли усилить свои позиции в конкурентной среде. В период с апреля 2020 года по август 2020 года кредитный портфель наиболее крупных игроков банковского сектора повысился на 4\%, у остальных участников банковского сектора выявлена в указанный период отрицательная динамика. Согласно заключению НКР эффективность бизнеса 30 крупнейших российских банков в I полугодии 2020 года повысилась. Участники указанного перечня финансовых учреждений имели сокращение общей прибыли, но смогли увеличить рентабельность деятельности до вычета резервов на возможные потери. Данный факт был обеспечен за счет следующих факторов:

- $\quad$ повышение чистой процентной маржи (NIM)

- $\quad$ повышение операционной эффективности

- повышение разрыва между стоимостью размещённых и привлечённых средств [3].

Также повышение рентабельности банковской деятельности обеспечило рациональное принятие решений в последние годы Банком России относительно тех 
финансовых учреждений, которые не соответствовали необходимым критериям банковского сектора.

С целью сокращения негативного влияния пандемии COVID-19 Банк России на регулярной основе осуществлял деятельность по смягчению условий денежно-кредитной политики, а также проводил меры, которые обеспечили поддержку бизнеса.

Важным последствием действия пандемии COVID-19 стала цифровая трансформация бизнес-процессов, реализуемых в банковском секторе, клиентского сервиса, а также цифровизация продуктовой линейки финансовых организаций.

Условием эффективной деятельности стало качество цифрового взаимодействия банков с клиентами, непрерывность предоставления услуг. Указанные аспекты обуславливают современный высокий уровень конкуренции в рамках рассматриваемой сферы.

Таким образом, пандемия COVID-19 повлияла на переориентацию целей бизнеса в сфере предоставления банковских услуг.

Ранее в качестве целей банковский сектор ставил перед собой развитие собственной инфраструктуры, максимизация прибыли, разработка новых продуктов. В настоящее время наблюдается переориентация на следующие приоритеты в деятельности банков:

- поиск новых возможностей и точек роста для осуществления бизнеспроцессов

- $\quad$ повышение операционной эффективности

- $\quad$ поиск возможностей для сокращения расходов.

Bce указанные цели обуславливают поиск возможностей для усиления позиций и индивидуальных преимуществ банков в жестких условиях конкуренции.

Другими характеристиками банковской сферы, сформированными в период действия пандемии COVID-19 стали временное сжатие кредитной активности и повышение объемов отчислений в резервы.

Большинство экспертов считают, что последствия пандемии не прекратят свое действие и влияние на рассматриваемую сферу в течение нескольких лет, как с финансовой, так и с операционной точки зрения.

Согласно предположениям экспертов в отчете Ассоциации банков России и компании Ernst \& Young Global Limited «Как опыт 2020 года повлияет на будущее банковского сектора России?», приоритетными факторами, которые будут осуществлять влияние на прибыль и капитал банков с 2021 года и на протяжении нескольких лет, станут окончание действия моратория на банкротство заемщиков и отмена регуляторных послаблений в 2021 году [1].

Среди приоритетных стратегических задач, согласно результатам исследования, станут совершенствование операционной среды, сокращение стоимости обслуживания клиентов.

Если рассматривать мнение управленческих команд ведущих российских банков о важных факторах, повлиявших на результаты их деятельности в 2020 году, то необходимо обратиться к результатам их опроса компанией «Интерфакс».

Результаты исследования выявили следующие направления деятельности участников банковского сектора в период пандемии COVID-19:

- $\quad$ снижение ключевой ставки до исторического минимума 4,25\% годовых

- $\quad$ работа в направлении цифровизации бизнеса и онлайн-обслуживания

- запуск госпрограмм льготного кредитования для бизнеса и ипотечных заемщиков

- миграция вкладов в инвестиции;

- $\quad$ развитие системы быстрых платежей (СБП) [2].

В настоящее время, основываясь на опыте работы в рамках действия жестких условий осуществления деятельности, участники банковского сектора выполнили анализ стратегических целей и задач, ранее сформированных на долгосрочный период и 
осуществили переориентацию на те направления совершенствования своей деятельности, которые обеспечат повышение эффективности деятельности и рост конкурентных преимуществ в условиях влияния последствий пандемии COVID-19.

B качестве таких целей и задач участники банковского сектора в приоритете выбирают следующие перспективные направления: работа над операционными рисками, повышение качества данных и оптимизация ПВР-моделей.

Указанные направления работы позволят повысить качество предоставления услуг клиентам, создать уникальные преимущества в жесткой конкурентной среде и ослабить негативное влияние состоявшегося кризиса в период пандемии COVID-19.

$$
* * *
$$

1. Ассоциация банков России. Ernst \& Young Global Limited. «Как опыт 2020 года повлияет на будущее банковского сектора России?» 2021.2 Режим ввода: [https://asros.ru/upload/iblock/f4f/Bank_Sector_EY_Rus_2021_Final.pdf] (Дата обращения: 22.09.2021)

2. МИГ «Интерфакс». Банковский сектор и "коронакризис"- когда год идет за двадцать. 20.12.2020. Режим ввода: [https://www.interfax.ru/business/742397] (Дата обращения: 22.09.2021)

3. НКР. Аналитическое исследование: Прогноз развития банковского сектора. 2020г. Режим ввода: [https://ratings.ru/files/research/banks/NCR_BanksOutlook_Oct2020.pdf] (Дата обращения: 22.09.2021)

\section{Киян М.А., Климовских Н.В. \\ Особенности формирования доходов сельскохозяйственных организаций и состояние их учетного обеспечения}

Кубанский государственный аграрный университет им. И.Т. Трубилина (Россия, Краснодар)

doi: 10.18411/trnio-12-2021-33

\section{Аннотация}

В статье определены главные особенности формирования доходов и расходов сельскохозяйственной организации, а также расписаны виды учета и контроля.

Ключевые слова: доходы и расходы, сельскохозяйственная организация, учет, организация контроля, контроль.

\section{Abstract}

The article identifies the main features of the formation of income and expenses of an agricultural organization, as well as describes the types of accounting and control.

Keywords: income and expenses, agricultural organization, accounting, organization of control, control.

Формирование дохода любой организации происходит за счет движения денежных средств. Проведение любой хозяйственной операции вызывает поступление денежных средств либо их расходование. Почти все направления операционной, инвестиционной и финансовой деятельности обслуживаются денежными средствами. Непрерывный процесс движения денежных средств во времени представляет собой денежный поток, обеспечивающий жизнеспособность организации. От полноты и своевременности обеспечения процесса снабжения, производства и сбыта продукции денежными ресурсами зависят результаты основной деятельности предприятия, степень его финансовой устойчивости и платежеспособности, конкурентные преимущества, необходимые для текущего и перспективного развития [2].

Формирование дохода сельскохозяйственной организации несколько отличается от формирования доходов иных организаций. Сельскохозяйственные предприятия могут быть акционерными обществами, товариществами, обществами с ограниченной ответственностью, кооперативами, унитарными предприятиями, крестьянско-фермерскими 